\title{
Right of Access to (Italian) Courts über alles? Legal Implications Beyond Germany's Jurisdictional Immunity
}

\author{
Paolo Palchetti
}

\begin{abstract}
The main consequence of Sentenza 238/2014 is that Germany has been denied jurisdictional immunities before Italian courts. However, the inflexible conception of the right of access to courts adopted by the Corte Costituzionale gives rise to a number of questions that go well beyond the issue at stake in Judgment $238 / 2014$. First, there is the issue of whether the right of access to justice should also prevail over the international customary rule on immunity from execution. Secondly, one may ask whether the need to protect the right provided by Article 24 of the Italian Constitution could trump the criteria established by Italian law for exercising civil jurisdiction in order to allow access to justice in respect to all international crimes, even those committed outside Italian territory and involving individuals having no link to Italy. Finally, there is the question of whether a sacrifice of the right of access to justice would be justified if alternative, non-judicial means of redress were available to the victims; in particular, whether an alternative means of redress should in any case ensure to each and every individual victim full compensation or whether instead, in light of the specific circumstances of the case-the fact that the crimes occurred in the course of an international armed conflict affecting hundreds of thousands of victims-such alternative means could provide only symbolic compensation based on a lump sum settlement. This chapter aims at exploring these and possibly other issues arising in connection to the broad interpretation of the principle of access to justice given by the Corte Costituzionale.
\end{abstract}

\footnotetext{
P. Palchetti $(\bowtie)$

University Paris 1 Panthéon Sorbonne, School of Law, Paris, France

e-mail: paolo.palchetti@univ-paris1.fr 


\section{Introduction}

International legal thinking has long been dominated by the perception of the state as a unitary subject. In strict legal terms, the unity of the state entails that the conduct of any state organ is to be regarded as the conduct of the state itself for the purposes of establishing international responsibility. It also entails that, in general, in international law and practice, it is the executive of the state that represents the state in its international relations and speaks for it at the international level'. ${ }^{1}$ The concept of the state as a unitary subject evidently relies on a legal fiction. Reality is more complex: behind the unitary veil of the state, there is a plurality of organs; these organs, at times, speak in different voices on questions of international law; they may have different priorities when performing acts that have international implications; and some of these organs are constitutionally independent from the executive.

The 'need to look behind the monolithic face of the State' becomes crucial for understanding the 'Italian concerns' following Judgment $238 / 2014 .^{2}$ In parallel with the interstate dispute between Germany and Italy, the question of Germany's immunity before Italian courts has generated an intense and prolonged confrontation between different organs of the Italian state. On the one side, there is a hyperactive judiciary, which appears determined to provide court access to victims through a controversial interpretation of international rules and, in the case of the Italian Constitutional Court (ItCC), irrespective of the costs in terms of compliance with the international rule of law. On the other side, there are political organs of the state that have shown a certain reluctance in engaging in meaningful political initiatives, both at the international and the intra-national level, for addressing the claims of victims. At an initial stage, the point of conflict concerned the determination of customary international rules on state immunity, with the judiciary and the executive expressing differing views as to the existence of an exception to immunity in cases of grave breaches of human rights and humanitarian law. Later the conflict centred around the implementation of the International Court of Justice's (ICJ) Jurisdictional Immunities Judgment: while the executive and parliament focused their efforts on securing Germany's immunity without apparently taking care of the fate of the victims' claims, the ItCC had no hesitation in giving precedence to the right to jurisdictional protection over compliance with the 2012 ICJ Judgment.

This internal confrontation explains the difficulty in discerning a unitary and coherent position of the state. It also explains the current deadlock in the conflicting approaches. Admittedly, after Judgment 238/2014 the room to manoeuvre available

\footnotetext{
${ }^{1}$ ICJ, Application of the International Convention on the Elimination of All Forms of Racial Discrimination (Georgia v Russian Federation), Preliminary Objections, Judgment of 1 April 2011, ICJ Reports 2011, 70, para 37.

${ }^{2}$ I borrowed this expression from Rosalyn Higgins, 'The Concept of "The State": Variable Geometry and Dualist Perceptions', in Laurence Boisson de Chazournes/Vera Gowlland-Debbas (eds), The International Legal System in Quest of Equity and Universality, Liber Amicorum Georges Abi-Saab (The Hague: Kluwer 2001), 547-561, at 561.
} 
to political organs appears limited. Yet, the Italian judiciary itself appears to be in no better position. With dozens of proceedings against Germany nearing their completion, the question of the enforcement of these judgments looms ahead. The ItCC may soon be called upon to assess the compatibility of the Italian Constitution with the customary international rule on immunity from execution. The choice would be a hard one. Denying immunity from execution because of its inconsistency with the Constitution would have far reaching consequences. Should the ItCC reach the opposite conclusion, the protection afforded to the victims by Judgment 238/2014 would be emptied of much of its substance.

While the main consequence of Judgment 238/2014 is that Germany is currently being denied jurisdictional immunity before Italian courts, the inflexible conception of the right of access to court adopted by the Corte Costituzionale has a number of implications that go well beyond the specific question of Germany's jurisdictional immunity. First, one may ask what could be the impact of the Judgment 238/2014 on the attitude of Italian political organs as regards sovereign immunity for acta iure imperii amounting to international crimes, and in particular whether the Italian government is now constitutionally bound not to invoke immunity if claims for compensation arising from such crimes are brought against Italy before the domestic judges of another state. Secondly, there is the issue of whether, following the logic underlying Judgment 238/2014, the right of access to justice should also prevail over the international customary rule on immunity from execution. Thirdly, there is the question of whether the need to protect the right provided by Article 24 of the Italian Constitution could trump the criteria established by Italian law for exercising civil jurisdiction in order to allow access to justice in respect to all international crimes, even those committed outside the Italian territory and involving individuals having no link with Italy. And, finally, one ought to consider the question of whether a sacrifice to the right of access to justice would be justified if alternative, non-judicial means of redress were available to the victims; even assuming that Sentenza 238/2014 leaves open the possibility of having recourse to alternative means of redress, it remains to be seen what basic requirements these alternative means must meet. These are some of the issues arising in connection to the broad interpretation of the principle of access to justice given by the Corte Costituzionale. They will be examined in turn in the following paragraphs.

\section{The Impact of Judgment 238/2014 on the Italian Government As Regards the Recognition of Immunity}

The Ferrini Judgment, ${ }^{3}$ as well as all subsequent judgments of Italian courts until 2012, were based on the premise that under international law there existed an exception to immunity in cases of international crimes and that denying immunity

\footnotetext{
${ }^{3}$ Corte di Cassazione, Judgment of 11 March 2004, No 5044/2004 (Ferrini), in Rivista di diritto internazionale 87 (2004), 540 et seq.
} 
to Germany, therefore, did not engage Italy's international responsibility. Before the ICJ, the Italian government defended the view of Italian courts on the conviction that a judgment could be regarded as authoritative by the different actors involved only if rendered after an extensive review of all the arguments put forward by Italian courts. In its Jurisdictional Immunities Judgment, the ICJ addressed these arguments and found that they had no basis in current international law. ${ }^{4}$ Unlike the Ferrini Judgment, Judgment 238/2014 is not based on the view that under international law Italy is entitled to deny immunity to Germany. The ItCC recognized that, because of the authority of the ICJ, the view expressed by that Court on the content of the law on state immunity has to be regarded as reflecting the current status of the law on the matter. ${ }^{5}$

While admitting that international law currently grants immunity for acta iure imperii, even if these acts amount to international crimes, there is little doubt that, by its Sentenza, the ItCC clearly aimed at contributing to the development of the international law on state immunity. Not only did it expressly note that a further reduction of the scope of the international rule on state immunity, particularly in cases of international crimes, would be 'a desirable — and desired by many-evolution of international law, ${ }^{6}$ it also referred to the role of domestic judges in the development of customary international law. In this respect, it could be said that with Judgment 238/2014 the ItCC contributed in setting the position of the Italian state with regard to the content of the rule on state immunity in cases of grave breaches of human rights and humanitarian law. It is less clear whether and to what extent the other organs of the state will follow this view when confronted with the question of state immunity beyond the cases brought against Germany.

So far, Italian political organs appear to have refrained from openly aligning themselves to the indications coming from the ItCC. Significantly, in proceedings pending before Italian courts against Germany, the executive has continued to plead in favour of a dismissal of the case for a lack of jurisdiction. ${ }^{7}$ Since in principle Judgment 238/2014 only concerned the applicability of the international rule of immunity by Italian courts in relation to a specific situation, the executive may have an interest in containing the impact of that Judgment by denying it any possible effect beyond its strict scope of application. In this respect, the fact that the executive might continue to defend the view that a state is entitled to immunity for acta iure imperii, irrespective of whether these acts amount to international crimes, has an impact on the attempt made by the ItCC to prompt a development of the international

\footnotetext{
${ }^{4}$ ICJ, Jurisdictional Immunities of the State (Germany v Italy: Greece intervening), Judgment of 3 February 2012, ICJ Reports 2012, 99, para 139.

${ }^{5}$ Corte Costituzionale, Judgment of 22 October 2014, No 238/2014, Conclusions in point of law, para 3.1.

${ }^{6}$ Ibid, para 3.3.

${ }^{7}$ See Karin Oellers-Frahm, 'A Never-Ending Story: The International Court of Justice-The Italian Constitutional Court-Italian Tribunals and the Question of Immunity', Heidelberg Journal of International Law 76 (2016), 193-202, at 195-196. See also Heike Krieger, chapter 'Sentenza 238/ 2014: A Good Case for Law-Reform?', in this volume.
} 
law of state immunity. Since the state practice must be assessed 'as a whole', the inconsistency in the practice of different organs within the Italian state would have the effect of reducing the weight to be given to that practice. ${ }^{8}$

From this perspective, it cannot be ruled out that Italy would invoke immunity if claims for compensation arising from international crimes committed by Italy during World War II (WWII) were brought against it before the domestic judges of another state. In the long run, however, particularly if Italian courts apply the principle upheld in Judgment 238/2014 to other situations and systematically deny immunity to states in cases involving the commission of international crimes, this inconsistent behaviour of the state would hardly be sustainable, let alone acceptable.

Finally, the possible impact of Judgment 238/2014 on Italy's compliance with the obligations stemming from the 2004 UN Convention on Jurisdictional Immunities of States and Their Property (UNCSI, or Convention) deserves a mention. At the time of the UNCSI's ratification in 2012, Italy made a declaration whereby it underlined 'that Italy understands that the Convention will be interpreted and applied in accordance with the principles of international law and, in particular, with the principles concerning the protection of human rights from serious violations'. In addition, Italy made clear its understanding 'that the Convention does not apply to the activities of armed forces and their personnel, whether carried out during an armed conflict as defined by international humanitarian law, or undertaken in the exercise of their official duties'. ${ }^{9}$ Clearly, the first declaration, which only concerns 'principles of international law', cannot have the effect of ensuring the compatibility of the obligations stemming from the UNCSI with Judgment 238/2014. By limiting the Convention's scope of application in respect to Italy, the second declaration may offer some form of legal protection to Italy. Ironically, a declaration that was made essentially in order to protect Italian armed forces from the risk of being subjected to the jurisdiction of another state by virtue of the exceptions to immunity provided by the UNCSI may now become the instrument for avoiding a possible breach of the UNCSI: by excluding the activities of armed forces from the UNCSI's scope of application, the denial of immunity by Italian judges for acts committed by foreign

\footnotetext{
${ }^{8}$ See, in this regard, the work of the International Law Commission (ILC) on the identification of customary international law. Conclusion No 7, as approved on second reading in 2018, provides as follows: '1. Account is to be taken of all available practice of a particular State, which is to be assessed as a whole. 2. Where the practice of a particular State varies, the weight to be given to that practice may, depending on the circumstances, be reduced.' It should be noted that in its commentary the ILC held the view that 'the practice of the executive branch is often the most relevant on the international plane and thus has particular weight in connection to the identification of customary international law, though account may need to be taken of the constitutional position of the various organs in question'. ILC, Draft Conclusions on the Identification of Customary International Law, Report on the Work of the Seventieth session (2018), UN Doc. A/73/10, 135. In the present case, as the position of judges exercising jurisdiction over Germany finds its basis in a decision of the ItCC, it would be hard to maintain that the view of the executive should be given more weight than that accorded to the judiciary.

${ }^{9}$ The text of Italy's declaration is available at https://treaties.un.org/Pages/ViewDetails.aspx? src $=I N D \& m t d s g \_n o=I I I-13 \&$ chapter $=3 \&$ clang $=\_$en\#EndDec.
} 
troops would amount only to a breach of obligations under customary international law.

It has been suggested that the Italian government should withdraw these declarations and make a new one aimed at ensuring the compatibility of Italy's obligations under the Convention with the principles stemming from Judgment 238/2014. ${ }^{10}$ No doubt, as recognized by the International Law Commission (ILC), '[t]he fact that a treaty provision reflects a rule of customary international law does not in itself constitute an obstacle to the formulation of a reservation to that provision'. ${ }^{11}$ By making a declaration whereby, for instance, it excludes the applicability of the general rule of immunity set forth in Article 5 of the 2004 Convention in cases involving pecuniary compensation for serious human rights violations, Italy would make clear the existence of a constitutional obstacle to the full implementation of the Convention within its legal order. It remains to be seen what the reaction from the other parties would be. Considering that the UNCSI aims at enhancing 'the rule of law and legal certainty' by contributing 'to the codification and development of international law and the harmonization of practice in this area', ${ }^{12}$ it would not be surprising if this reservation could be regarded as running contrary to the object and purpose of the Convention.

\section{A 'Containment Strategy'?: Immunity from Jurisdiction and Immunity from Execution}

Among the possible solutions to the situation created by Judgment 238/2014, one is, most simply, to accept this situation on the assumption that the judgments of Italian courts ordering Germany to pay compensation to the victims and their heirs will have little practical effects thanks to the protection afforded to states' properties by the customary international rule on immunity from execution. Such a minimalistic approach, aimed only at containing the consequences of Judgment 238/2014, relies on the fact that since the ItCC's Judgment 238/2014 only deals with immunity from jurisdiction, by virtue of Article 10 of the Italian Constitution, the international rule on immunity from execution continues to produce its effect within the Italian legal order. ${ }^{13}$ The distinction between immunity from jurisdiction and immunity from

\footnotetext{
${ }^{10}$ Francesco Salerno, 'Giustizia costituzionale versus giustizia internazionale nell'applicazione del diritto internazionale generalmente riconosciuto', Quaderni Costituzionali 35 (2015), 33-58, at 57.

${ }^{11}$ See Guideline 3.1.5.3 of the Guide to Practice on Reservations to Treaties adopted by the ILC in 2011, UN Doc. A/66/10, para 75.

${ }^{12}$ See the preamble of the UN Convention on Jurisdictional Immunities of States and Their Property (2 December 2004), UN Doc A/RES/59/38, UN Doc A/59/49, 486 (not yet in force).

${ }^{13}$ See ItCC, Judgment 238/2014 (n 5), Conclusions in point of law, para 1 ('the referring judge limits the questions raised to the issue of the jurisdiction to examine the claim for compensation for damages, and does not include the issue of enforcement action'). See also Heike Krieger, chapter 'Sentenza 238/2014: A Good Case for Law-Reform?', in this volume.
} 
execution has so far been respected by Italian courts. Thus, the Court of Appeals of Milan recognized that under customary international law no post-judgment measures of constraint can be taken against the property of a state that is in use or intended to be used for non-commercial government purposes; for that reason, it confirmed the decision of the Tribunal of Como ordering that the mortgage on Villa Vigoni inscribed at the land registry be cancelled. ${ }^{14}$

The importance attached by political organs to the protection offered by immunity from execution is reflected in a new statutory provision adopted a few weeks after Judgment 238/2014. Article 19 bis of Italian Law-decree No 132, converted into Law No 162 of 10 November 2014, exempts from attachment any amount of money in the availability of subjects involved in one of the following functions: diplomatic mission of the state or its consular posts, special missions, missions to international organizations or delegations to organs of international organizations or to international conferences. ${ }^{15}$ Interestingly, such an exemption is only conditional on a declaration made by the head of the diplomatic mission, by which it is said that the relevant bank account is exclusively intended for use for the abovementioned functions. $^{16}$

No doubt, from the viewpoint of international law, the distinction between immunity from jurisdiction and immunity from execution rests on solid grounds. ${ }^{17}$ In its Jurisdictional Immunities Judgment, the ICJ observed that ' $[\mathrm{t}]$ he rules of customary international law governing immunity from enforcement and those governing jurisdictional immunity (understood stricto sensu as the right of a State not to be the subject of judicial proceedings in the courts of another State) are distinct, and must be applied separately'. ${ }^{18}$ The ItCC, in a judgment rendered in 1992, also recognized that the rule on immunity from execution is autonomous and distinct from that on immunity from jurisdiction. ${ }^{19}$

However, relying on the protection afforded to Germany by the international rule on immunity from execution can hardly be regarded as a satisfactory solution. First, as already observed, it is likely that sooner or later the question of the compatibility

\footnotetext{
${ }^{14}$ Corte d'Appello di Milano, Order of 25 March 2015, No 4183/2013.

${ }^{15}$ Italian Law 10 November 2014, No 162.

${ }^{16}$ On this point, see the critical remarks of Benedetto Conforti, 'Il legislatore torna indietro di circa novant'anni: la nuova norma sull'esecuzione su conti correnti di Stati stranieri', Rivista di diritto internazionale 98 (2015), 558-561. See also Riccardo Pavoni, chapter 'A Plea for Legal Peace', in this volume.

${ }^{17}$ On the separateness of the regimes governing immunity from jurisdiction and immunity from execution see, among others, Ian Sinclair, 'The Law of Sovereign Immunity: Recent Developments', Recueil des cours 168 (1980-II), 115-284, at 218; August Reinisch, 'State Immunity from Enforcement Measures', in Gerhard Hafner/Marcelo Kohen/Susan Breau (eds), State Practice Regarding State Immunity (Leiden/Boston: Martinus Njhoff 2006), 151-166; Xiaodong Yang, State Immunity in International Law (Cambridge: CUP 2012), at 347 et seq.

${ }^{18} \mathrm{ICJ}$, Jurisdictional Immunities (n 4), para 113.

${ }^{19}$ Corte Costituzionale, Judgment of 15 July 1992, No 329/1992, in Rivista di diritto internazionale 75 (1992), 356 et seq.
} 
of such a rule with fundamental constitutional principles will be brought before the ItCC. While it is to be expected that the ItCC will take into account that 'the immunity from enforcement enjoyed by States in regard to their property situated on foreign territory goes further than the jurisdictional immunity enjoyed by those same States before foreign courts', ${ }^{20}$ the outcome of any future decision by the ItCC on immunity from execution is difficult to predict. In this respect, the fact that political organs have taken no initiative to address the substantial concerns underlying Judgment 238/2014 may become a factor that, in the overall assessment of the weight to be given to the competing interests at stake, risks weakening the arguments in favour of preserving immunity from execution.

Even if the ItCC were to recognize the compatibility of this international rule with the Italian Constitution, the presence of dozens of final judgments ordering Germany to pay compensation risks becoming a perennial source of tension, with the claimants attempting to enforce them through measures of constraint directed against German property in use for other than government non-commercial purposes. Such an outcome would also be extremely frustrating for the victims, who after having been told that they have a right to a judge and after having been awarded compensation would discover that they have substantially little, if any, chance of having their judgments enforced. Their situation would be similar to that of the relatives of the victims of the Distomo massacre, who were found to be entitled to compensation from the German state but were unable to obtain the execution of the judgment on account of the Greek state's refusal to allow them to bring enforcement proceedings against Germany. ${ }^{21}$ As that precedent shows, victims could hardly hope to obtain some form of redress by lodging a complaint before the European Court of Human Rights (ECtHR). While recognizing that ' $[t]$ he right of access to a tribunal would be illusory if a Contracting state's legal system allowed a final, binding judicial decision to remain inoperative to the detriment of one party', in Kalogeropoulou the ECtHR denied that the conduct of Greek authorities amounted to an unjustified interference with the complainants' right of access to a tribunal. The ECtHR relied on the existence of a generally recognized rule on state immunity from execution to conclude that 'although the Greek courts ordered the German state to pay damages to the applicants, this did not necessarily oblige the Greek state to ensure that the applicants could recover their debt through enforcement proceedings in Greece'. ${ }^{22}$

\footnotetext{
${ }^{20} \mathrm{ICJ}$, Jurisdictional Immunities (n 4), para 113.

${ }^{21}$ On this case see ICJ, Jurisdictional Immunities (n 4), paras 30-31.

${ }^{22}$ ECtHR, Kalogeropoulou and Others v Greece and Germany, Decision of 12 December 2002, Application No 59021/00.
} 


\section{Beyond State Immunity: The Criteria for Establishing the Jurisdiction of Italian Judges}

Italian courts have already shown a certain willingness to apply the principle upheld in Judgment 238/2014 beyond the cases brought against Germany. In its Judgment of 29 October 2015 in the Opačić case, a criminal division of the Court of Cassation relied on Judgment 238/2014 to justify the denial of immunity to Serbia in relation to a request for compensation advanced by the heirs of Italian victims of war crimes committed in the territory of the Former Yugoslavia in $1992 .^{23}$ This Judgment of the Court of Cassation is remarkable as it appears to expand the breadth of situations in which a denial of immunity would be justified. In particular, the Court of Cassation interpreted ItCC's Sentenza 238/2014 to the effect that in cases of international crimes immunity must be denied irrespective of whether there are alternative remedies available to the complainants in order to recover damages. ${ }^{24}$ Under this interpretation, the right of access to justice as provided by Article 24 of the Italian Constitution could not suffer any limitation even if some alternative forms of redress were available to the victims of international crimes committed by a foreign state. Should one accept this interpretation of Judgment 238/2014, it would follow that the introduction of some alternative form of protection following the conclusion of an agreement between Germany and Italy would not justify the possibility of restoring the immunity of Germany in accordance to international law. ${ }^{25}$

In Flatow and Eisenfeld, the Court of Cassation was called upon to rule on an exequatur request regarding a judgment of a US court condemning Iran to pay a sum of money to compensate the heirs of victims of acts of terrorism committed in Israel. In its Judgments of 28 October 2015, the Court of Cassation recognized that, according to the principle upheld in Judgment 238/2014, Iran would not have been entitled to immunity for acts amounting to crimes against humanity. In the end, however, it denied exequatur because of the non-fulfilment of the criteria established by Italian law for exercising civil jurisdiction. ${ }^{26}$

The Judgments in Flatow and Eisenfeld reveal a possible tension between the criteria for exercising civil jurisdiction and the effective protection of the right of

\footnotetext{
${ }^{23}$ Corte di Cassazione, Judgment of 29 October 2015, No 43696/2015 (Opačić).

${ }^{24}$ See ibid, para 5.2.1, Conclusions in point of law: 'Judgment 238/2014 of the Constitutional Court did not pose the condition that, in order to establish the jurisdiction over foreign states for war crimes, it is required that there is no other possibility for the victims to obtain redress for the damages suffered' (translated by the author). On this Judgment, see Riccardo Pavoni, 'How Broad is the Principle Upheld by the Italian Constitutional Court in Judgment No. 238?', Journal of International Criminal Justice 14 (2016), 573-585, at 577.

${ }^{25} \mathrm{I}$ will return to this issue in the next section.

${ }^{26}$ Corte di Cassazione, Judgment of 28 October 2015, No 21946/2015 (Flatow); Corte di Cassazione, Judgment of 28 October 2015, No 21947/2015 (Eisenfeld).
} 
access to justice as interpreted by the ItCC. Under the criteria established by Italian law, civil jurisdiction is based on some connection between the case and the forum. ${ }^{27}$ This means that, in the absence of the required nexus, access to justice may be precluded by the lack of jurisdiction of Italian courts. In Flatow and Eisenfeld, the Court of Cassation did not uphold the claim of the applicants that jurisdiction could be based on an international rule authorizing universal civil jurisdiction in cases of international crimes. It also excluded that Judgment 238/2014 had the effect of introducing the principle of universal civil jurisdiction in the Italian legal order. By strictly abiding by the criteria established by Italian law for exercising civil jurisdiction, the Court of Cassation substantially precluded access to justice in a situation in which - as the Court itself admitted - the principle of jurisdictional protection would have justified the denial of immunity to the respondent state. However, while the distinction between jurisdiction and immunity is unobjectionable, the whole situation appears to be characterized by a certain inconsistency: ${ }^{28}$ if, in cases of claims against a foreign state for international crimes, the right to access to justice must be given a prominent value, it is hard to explain why access to justice must not be precluded by the international rule of state immunity but can be precluded by domestic laws through which Italy delimits the scope of jurisdiction of its own judges. In this respect, the Judgments in Flatow and Eisenfeld illustrate that the decision of the ItCC might have an impact that goes beyond the question of the immunity enjoyed by foreign states before Italian courts. In fact, after Judgment 238/2014, the compatibility between the right of access to justice as interpreted by the ItCC and domestic rules barring the exercise of jurisdiction over claims for compensation arising from international crimes committed by a foreign state cannot be taken for granted. Should the ItCC, following the path inaugurated by Judgment 238/2014, find that any such limitation to the jurisdiction of Italian judges would be contrary to Article 24 of the Italian Constitution, the dispute between Italy and Germany on the question of Germany's immunity would risk becoming for Italy only the first in a long list of disputes with other states.

\footnotetext{
${ }^{27}$ According to Salerno, 'Giustizia costituzionale' 2015 (n 10), 54, in cases against a foreign state and relating to acta iure imperii of that state, Art 3(2) of Italian Law No 218 of 31 May 1995 permits grounding the jurisdiction of Italian courts if, in the absence of other connections, the applicant resides in Italy. However, in Flatow and in Eisenfeld the Court of Cassation denied that the residence in Italy of the applicant was sufficient to ground the jurisdiction of Italian courts.

${ }^{28}$ For critical comments on the solution retained by the Court of Cassation, see Pavoni, 'How Broad' 2016 (n 24), 584.
} 


\section{Judgment 238/2014 and Its Silences: An Interstate Agreement on Compensation As an Alternative to Individual Access to Italian Courts?}

In its Jurisdictional Immunities Judgment the ICJ started its examination of the question concerning the alleged violation of Germany's immunity by recalling that the acts constituting the object of the proceedings before Italian courts 'can only be described as displaying a complete disregard for the "elementary considerations of humanity", and that Germany 'accepts that these acts were unlawful and stated before this Court that it "is fully aware of [its] responsibility in this regard", 29 At the same time, the Court noted that 'since the dismissal of Italy's counter-claim, it no longer has before it any submissions asking it to rule on the question of whether Germany has a duty of reparation towards the Italian victims of the crimes committed by the German Reich and whether it has complied with that obligation in respect of all those victims, or only some of them'. ${ }^{30}$ While the ICJ did not rule upon the latter questions, it made two remarks that the Parties were expected to take seriously into account, irrespective of the fact that they were not formally binding upon them.

In a first passage the ICJ noted that, while granting immunity to Germany had the effect of precluding judicial redress for the Italian victims, their claims 'could be the subject of further negotiation involving the two states concerned, with a view to resolving the issue'. ${ }^{31}$ Thus, the Court itself seemed to invite the Parties to consider the possibility of engaging in a negotiation, on the assumption that negotiation and not recourse to the domestic courts of one state is a preferable way of dealing with this matter. As to the object of this negotiation, it should be stressed that the Court referred to negotiation over 'the claims arising from the treatment of the Italian military internees (...) together with other claims of Italian nationals which have allegedly not been settled-and which formed the basis for the Italian proceedings'. ${ }^{32}$ This is a crucial point. The negotiation envisaged by the ICJ as the alternative to an (unlawful) recourse to domestic courts has to deal with the claims of the individual victims. In this respect, the fact that Germany and Italy, after the ICJ's Jurisdictional Immunities Judgment, may have agreed to engage in common cultural initiatives, such as the construction of documentation centres or memorials, without taking care to address the claims of the victims can hardly be regarded as a solution going in the direction indicated by the ICJ, the more so if one considers that the ICJ speaks of 'negotiation involving the two States' ("négociations impliquant les deux Etats') and not of 'negotiations between the two States'. As it is connoted by the word 'involving', other actors should have been given a role in the negotiation. In particular, the victims themselves should have had a role. The two states should have

\footnotetext{
${ }^{29} \mathrm{ICJ}$, Jurisdictional Immunities (n 4), para 52.

${ }^{30} \mathrm{ICJ}$, Jurisdictional Immunities (n 4), para 48.

${ }^{31} \mathrm{ICJ}$, Jurisdictional Immunities (n 4), para 104.

${ }^{32}$ Ibid.
} 
at least consulted the victims or the associations of victims. To my knowledge, nothing of the sort occurred.

The ICJ Judgment provides an additional argument in favour of an agreement aimed at addressing the individual claims of the victims. It was Germany, with the establishment in 2000 of the Foundation 'Rememberance, Responsibility and Future' (Erinnerung, Verantwortung und Zukunft), that first proposed the possibility of individual compensation for the victims of forced labour, including Italian victims. Thousands of Italian Military Internees (IMIs) lodged requests for compensation and had a reasonable expectation to be regarded as entitled to receive it. However, more than 127,000 of the 130,000 requests for compensation lodged by Italian victims were rejected. The ICJ took a very clear position on Germany's decision to reject the requests advanced by IMIs: 'it is a matter of surprise-and regret - that Germany decided to deny compensation to a group of victims on the ground that they had been entitled to a status which, at the relevant time, Germany had refused to recognize, particularly since those victims had thereby been denied the legal protection to which that status entitled them'. ${ }^{33}$ An opposition of principle towards the establishment of a mechanism for addressing individual claims of compensation is already difficult to understand, as it was Germany that in 2000 envisaged such a possibility for the victims of forced labour. Insisting on that opposition after the ICJ's strong censure would likely be perceived by Italian victims as a form of discrimination against them and would risk undermining the significance of the other common initiatives that Italy and Germany may agree to undertake in relation to the crimes committed during WWII.

No doubt a political initiative involving Germany and Italy and aimed at establishing a mechanism for addressing the reparation claims of the victims while at the same time restoring Germany's immunity before Italian courts would not only be in line with the views expressed by the ICJ in its Jurisdictional Immunities Judgment; such an outcome would also represent the most dignified way to put an end to this long-standing dispute. ${ }^{34}$ It is not clear, however, whether an interstate agreement on compensation might be regarded by the ItCC as an adequate alternative route for providing protection to the rights of the victims, thereby justifying a limitation to the right of access to court and the recognition of Germany's immunity. In fact, Judgment 238/2014 does not clarify whether or to what extent a sacrifice to the right of jurisdictional protection would be justified if alternative, non-judicial means of redress were available to the victims. The ItCC failed to assess the possible

\footnotetext{
${ }^{33} \mathrm{ICJ}$, Jurisdictional Immunities (n 4), para 99.

${ }^{34}$ An agreement between Germany and Italy may be concluded without the need to reopen the question of whether Germany has an obligation of reparation for serious violations of international humanitarian law against Italian victims. As already mentioned, in 2010 it was Italy that asked the Court, by way of a counterclaim, to establish that Germany had violated such obligation. Germany opposed the counterclaim. In the end, the ICJ found that it had no jurisdiction to rule upon it. In a pragmatic way, the two states may now accept their having different views as to the scope and effect of the waiver clause contained in the 1947 Italy's Peace Treaty without this preventing them from reaching an agreement over the compensation of Italian victims.
} 
role of alternative forms of protection. Despite the serious implications of Judgment 238/2014, no attempt was made to delineate a possible way out.

While the Court has taken a rigid stance as to the possibility of sacrificing the principle of jurisdictional protection, the conclusion of an interstate agreement would inevitably have an impact on the overall assessment of the different interests at stake. Arguably, in balancing the principle of jurisdictional protection with Italy's compliance with international law, the introduction of some alternative means of protecting the rights of the victims could tip the balance in favour of a solution that leads to better harmonization between the two conflicting interests. ${ }^{35}$

Whether an interstate agreement on compensation will be regarded as an adequate alternative remedy justifying the sacrifice of the right of access to justice will also depend on the terms of the agreement. In this respect, it is to be expected that one of the most controversial points in a possible negotiation will concern the amount of compensation due to the victims. Judgment 238/2014 gave no indication on whether an alternative means of redress should in any case ensure to each and every individual victim full compensation or whether instead, in light of the specific circumstances of the case-the fact that the crimes occurred in the course of an international armed conflict affecting hundreds of thousands of victims-it could provide only compensation based on a lump-sum settlement. While in past cases Germany only provided symbolic compensation to victims, ${ }^{36}$ there is the risk that a mechanism providing for only symbolic compensation would not be regarded by the ItCC as an adequate alternative remedy. On this and similar issues, such as that of determining the individuals that could benefit from a future reparation scheme, a flexible approach that accepts forms of redress other than full compensation appears to be warranted.

The negotiation's method of conduct may also matter. Given the nature of the dispute, the multitude of different actors involved, and the criticism and diffidence frequently addressed against the conduct of political organs in this long-standing affair, careful consideration should be given to the possibility of informing and consulting the main stakeholders (as suggested by the ICJ), as well as respecting certain standards of transparency.

\footnotetext{
${ }^{35}$ On this point, see also Remo Caponi, 'A Fresh Start: How to Resolve the Conflict between the ICJ and the Italian Constitutional Court', VerfBlog, (28 January 2015), available at http:// verfassungsblog.de/fresh-start-resolve-conflict-icj-italian-constitutional-court/; Remo Caponi, 'Immunità dello Stato dalla giurisdizione, negoziato diplomatico e diritto di azione nella vicenda delle pretese risarcitorie per i crimini nazisti', Giurisprudenza costituzionale 5 (2014), 3908-3915, at 3908 et seq. See also Riccardo Pavoni, chapter 'A Plea for Legal Peace', in this volume.

${ }^{36}$ On the decision of the German government to pay a symbolic financial compensation to some 4,000 Russian prisoners of war, see Oellers-Frahm, 'A Never-Ending Story' 2016 (n 7), at 202; see also Giovanni Boggero/Karin Oellers-Frahm, chapter 'Between Cynicism and Idealism', in this volume.
} 


\section{Conclusion}

For Italy, the consequences unleashed by Judgment 238/2014 are not confined to the question of Germany's jurisdictional immunities before Italian courts and to the ensuing risk that Germany will once more bring the case before the ICJ. After Judgment 238/2014, the Italian government faces the problem of either continuing to defend the view that a state is entitled to immunity for acta iure imperii, irrespective of whether these acts amount to international crimes, or aligning itself to the indications coming from the ItCC, which includes presenting a new declaration aimed at ensuring the compatibility of Italy's obligations under the 2004 UN Convention with the principles stemming from Judgment 238/2014. Italian courts will sooner or later be confronted with the problem of the execution of the judgments condemning Germany for the crimes committed during WWII. In the meantime, following the principle established by Judgment 238/2014, the Court of Cassation denied immunity to Serbia. While — so far - the same Court has resisted any attempt to introduce the principle of universal civil jurisdiction into the Italian legal order, the risk of Italian courts becoming an attractive forum for litigations against foreign states is high.

Judgment 238/2014 had the merit of forcefully raising the question of the rights of the victims of grave breaches of human rights and of the way in which these rights are to be protected. Unfortunately, by focusing exclusively on individual access to justice and on the need to promote an evolution of the law of state immunity, it raises more questions than it answers. Some of the consequences of Sentenza may be unintentional but, in the absence of a new decision clarifying the conditions under which a sacrifice to the right of jurisdictional protection would be justified, the current situation is one of legal uncertainty. In this scenario, political organs should attempt to provide some solutions. A political initiative aimed at addressing some of the concerns behind Judgment 238/2014 would constitute a first, important step in that direction.

\section{References}

Caponi, Remo, 'A Fresh Start: How to Resolve the Conflict between the ICJ and the Italian Constitutional Court', VerfBlog, (28 January 2015), available at http://verfassungsblog.de/ fresh-start-resolve-conflict-icj-italian-constitutional-court/

Caponi, Remo, 'Immunità dello Stato dalla giurisdizione, negoziato diplomatico e diritto di azione nella vicenda delle pretese risarcitorie per i crimini nazisti', Giurisprudenza costituzionale 5 (2014), 3908-3915

Conforti, Benedetto, 'Il legislatore torna indietro di circa novant'anni: la nuova norma sull'esecuzione su conti correnti di Stati stranieri', Rivista di diritto internazionale 98 (2015), $558-561$

Higgins, Rosalyn, 'The Concept of "The State": Variable Geometry and Dualist Perceptions', in Laurence Boisson de Chazournes/Vera Gowlland-Debbas (eds), The International Legal System 
in Quest of Equity and Universality, Liber Amicorum Georges Abi-Saab (The Hague: Kluwer 2001), 547-561

Oellers-Frahm, Karin, 'A Never-Ending Story: The International Court of Justice-The Italian Constitutional Court-Italian Tribunals and the Question of Immunity', Heidelberg Journal of International Law 76 (2016), 193-202

Pavoni, Riccardo, 'How Broad is the Principle Upheld by the Italian Constitutional Court in Judgment No. 238?', Journal of International Criminal Justice 14 (2016), 573-585

Reinisch, August, 'State Immunity from Enforcement Measures', in Gerhard Hafner/Marcelo Kohen/Susan Breau (eds), State Practice Regarding State Immunity (Leiden/Boston: Martinus Njhoff 2006), 151-166

Salerno, Francesco, 'Giustizia costituzionale versus giustizia internazionale nell'applicazione del diritto internazionale generalmente riconosciuto', Quaderni Costituzionali 35 (2015), 33-58

Sinclair, Ian, 'The Law of Sovereign Immunity: Recent Developments', Recueil des cours 168 (1980-II), 115-284

Yang, Xiaodong, State Immunity in International Law (Cambridge: CUP 2012)

Open Access This chapter is licensed under the terms of the Creative Commons Attribution 4.0 International License (http://creativecommons.org/licenses/by/4.0/), which permits use, sharing, adaptation, distribution and reproduction in any medium or format, as long as you give appropriate credit to the original author(s) and the source, provide a link to the Creative Commons license and indicate if changes were made.

The images or other third party material in this chapter are included in the chapter's Creative Commons license, unless indicated otherwise in a credit line to the material. If material is not included in the chapter's Creative Commons license and your intended use is not permitted by statutory regulation or exceeds the permitted use, you will need to obtain permission directly from the copyright holder. 